\title{
PENGARUH PEMANFAATAN INTERNET, LINGKUNGAN DAN MOTIVASI BELAJAR TERHADAP PRESTASI BELAJAR SISWA SMK
}

\author{
Anggoro Dwi Listyanto \\ SMK Negeri Tepus Gunungkidul \\ aang_85@yahoo.com \\ Sudji Munadi \\ Universitas Negeri Yogyakarta \\ sudji.munadi@yahoo.co.id
}

\begin{abstract}
Abstrak
Penelitian ini bertujuan untuk mendapatkan informasi tentang 1) pemanfaatan internet, lingkungan, dan motivasi belajar; 2) pengaruh pemanfaatan internet, lingkungan dan motivasi belajar terhadap prestasi belajar siswa mata pelajaran dasar kompetensi kejuruan kompetensi keahlian teknik audio video SMK Negeri se-Kabupaten Gunungkidul. Metode yang digunakan dalam mengumpulkan data adalah kuesioner dan tes. Teknik analisa data dalam penelitian ini adalah statistik deskriptif dan analisis regresi. Hasil penelitian ini menunjukkan bahwa 1) kecenderungan pemanfaatan internet siswa terdapat pada kategori cukup; 2) lingkungan siswa terdapat pada kategori cukup; 3) motivasi belajar siswa terdapat pada kategori cukup; 4) prestasi belajar siswa terdapat pada kategori cukup. Hasil uji hipotesis menunjukkan bahwa 1) terdapat pengaruh antara pemanfaatan internet terhadap prestasi belajar siswa; 2) terdapat pengaruh antara lingkungan terhadap prestasi belajar siswa; 3) terdapat pengaruh antara motivasi belajar terhadap prestasi belajar siswa; 4) terdapat pengaruh antara pemanfaatan internet, lingkungan, dan motivasi belajar secara bersama-sama terhadap prestasi belajar siswa mata pelajaran dasar kompetensi kejuruan kompetensi keahlian teknik audio video SMK Negeri se-Kabupaten Gunungkidul.
\end{abstract}

Kata kunci: internet, lingkungan, motivasi belajar, prestasi belajar, motivasi, prestasi, belajar

\section{THE EFFECT OF INTERNET USE, ENVIRONMENT AND LEARNING MOTIVATION ON THE ACHIEVEMENT OF THE STUDENTS OF SMK}

\begin{abstract}
This study aims to gain a general description about 1) the use of the Internet, the environment, and learning motivation on the achievement of the students; 2) the effect of the Internet use, environment, and learning motivation on the achievement of the students of the basic subject vocational competencies, audio video engineering, state SMK's in Gunungkidul Regency. The methods used in collecting the data were questionnaires and test. The data analysis was a descriptive statistic and regression analysis. The results of this study indicate that 1) the trend of using the Internet is in the sufficient category; 2) the environment is in the sufficient category; 3 ) the learning motivation is in the sufficient category; 4) the achievement is in sufficient category. The result of hyothesis testing shows that 1) there is an effect of the Internet use on the achievement; 2) there is an effect of the environments on the achievement; 3) there is an effect of learning motivation on the achievement; 4) there is an effect of the Internet use, the environment, and the learning motivation on the achievement of the students of the basic subject of vocational competency audio video engineering, state SMK's in Gunungkidul Regency.
\end{abstract}

Keywords: internet, environment, learning motivation, learning achievement, motivation, achievement, learning 


\section{PENDAHULUAN}

Pendidikan merupakan hal yang utama dalam proses peningkatan kualitas sumber daya manusia. Melalui pendidikan seseorang akan mendapatkan bekal dalam menghadapi kehidupan di masa mendatang karena dengan pendidikan kehidupan seseorang diharapkan akan lebih baik. Usaha yang dilakukan adalah dengan mendirikan lembaga pendidikan. Sekolah merupakan lembaga pendidikan formal yang memegang peranan sangat penting dalam meningkatkan kualitas sumber daya manusia. Selain itu sekolah sebagai lembaga formal juga berusaha semaksimal mungkin dalam meningkatkan prestasi belajar siswa.

Prestasi menentukan berhasil tidaknya pendidikan, karena itu prestasi memiliki fungsi yang penting bagi siswa dalam dunia pendidikan. Menurut Hamalik (2003: 152) "prestasi belajar adalah hasil atas kepandaian atau keterampilan yang dicapai oleh individu untuk memperoleh perubahan tingkah laku yang baru, secara keseluruhan sebagai hasil pengalaman individu dalam interaksinya dengan lingkungan", sedangkan menurut Sukmadinata (2003:101) "prestasi belajar adalah realisasi dari kecakapan-kecakapan potensial atau kapasitas yang dimiliki seseorang". Pada dasarnya prestasi merupakan hasil dari usaha belajar siswa yang aktif dalam meningkatkan prestasinya. Prestasi belajar pada hakekatnya merupakan pencerminan dari usaha belajar. Semakin baik usaha belajar semakin baik pula prestasi belajar yang dicapai. Jadi prestasi merupakan tolok ukur atas keberhasilan prestasi siswa setelah melakukan proses belajar.

Dalam kegiatan belajar mengajar yang ada di sekolah, prestasi belajar dinyatakan dalam bentuk angka-angka, begitu juga di Sekolah Menengah Kejuruan (SMK). Prestasi belajar yang diperoleh oleh siswa dituangkan dalam sebuah buku laporan hasil belajar siswa. Nilai laporan hasil belajar siswa bukan satu-satunya tolok ukur keberhasilan prestasi belajar siswa. Selain dari nilai laporan hasil belajar siswa, nilai Ujian Nasional merupakan salah satu penentu kelulusan. Nilai rata-rata Ujian Nasional teori kejuruan tahun pelajaran 2011/2012 untuk Kabupaten Gunungkidul memperoleh peringkat ke-5 di Daerah Istimewa Yogyakarta yang berarti peringkat yang paling rendah. Berikut ini adalah daftar peringkat hasil Ujian Nasional teori kejuruan di Daerah Istimewa Yogyakarta.

Tabel 1. Daftar Peringkat Nilai UN Teori Kejuruan se-Provinsi Daerah Istimewa Yogyakarta Tahun Pelajaran 2011/2012

\begin{tabular}{ccc}
\hline Peringkat & $\begin{array}{c}\text { Kabupaten/ } \\
\text { Kota }\end{array}$ & $\begin{array}{c}\text { Nilai Rata-rata UN } \\
\text { Teori Kejuruan Tahun } \\
\text { Pelajaran 2011/2012 }\end{array}$ \\
\hline 1 & Sleman & 8,09 \\
2 & Kulonprogo & 8,04 \\
3 & Bantul & 8,01 \\
4 & Yogyakarta & 7,97 \\
5 & Gunungkidul & 7,97 \\
\hline
\end{tabular}

sumber: http://www.pendidikan-diy.go.id/? view $=\mathrm{v}$ berita\&id $\mathrm{sub}=2692$

Hasil studi pendahuluan ke SMK Negeri se-Kabupaten Gunungkidul kompetensi keahlian teknik audio video menunjukkan bahwa siswa masih minim akan sumber belajar yang digunakan dalam proses belajar mengajar karena sebagian besar siswa hanya mengandalkan materi pelajaran dari guru. Selain materi pelajaran dari guru masih sedikit koleksi buku-buku tentang teknik audio video yang ada di perpustakaan dan siswa juga banyak yang tidak memiliki buku-buku tentang teknik audio video karena di Kabupaten Gunungkidul toko buku masih sedikit dan tidak komplit sehingga siswa masih kurang dalam hal sumber belajar. Salah satu sumber belajar yang digunakan dalam dunia pendidikan adalah internet, karena dengan internet guru akan lebih mudah memberikan informasi tentang materi pelajaran kepada siswa, karena siswa hanya disuruh membuka suatu situs yang telah ditunjukkan oleh guru tentang situs yang relevan dengan mata pelajaran yang sedang diajarkan sehingga dapat didiskusikan bersama sebagai bahan pelajaran. Dengan internet, siswa kompetensi keahlian teknik audio video dapat mencari makalah tentang cara-cara membuat amplifier, mereparasi DVD Player, mereparasi televisi dan masih banyak lagi yang berhubungan dengan teknik audio video. Letak geografis Kabupaten Gunungkidul yang sebagian besar daerahnya terdapat perbukitan mengakibatkan kesulitan untuk mendapatkan koneksi internet. Padahal dalam pembelajaran, internet sangat penting 
bagi siswa supaya tidak ketinggalan informasi karena dengan internet siswa dapat mencari sumber informasi yang paling aktual dan dapat mencari referensi tentang materi pelajaran yang sedang diajarkan.

Internet akan membawa dampak yang positif dan negatif bagi lingkungan pendidikan. Lingkungan pendidikan adalah suatu institusi atau kelembagaan di mana pendidikan itu berlangsung dan lingkungan tersebut akan mempengaruhi proses pendidikan. Lingkungan merupakan faktor yang sangat menentukan dan mempunyai pengaruh yang besar terhadap siswa karena seseorang yang tinggal dalam suatu lingkungan secara tidak sadar lingkungan tersebut akan mempengaruhi siswa tersebut. Siswa yang berada pada lingkungan yang baik maka akan dapat memberikan pengaruh yang baik pula bagi perkembangan siswa tersebut dan begitu juga sebaliknya, lingkungan yang tidak baik juga dapat memberikan pengaruh yang tidak baik bagi perkembangan siswa tersebut.

Selain lingkungan, motivasi juga berperan dalam peningkatan prestasi belajar siswa. Menurut Sardiman (2005: 73) motivasi adalah daya penggerak yang telah menjadi aktif. Motif menjadi aktif pada saat-saat tertentu, terutama bila kebutuhan untuk mencapai tujuan sangat dirasakan atau mendesak. Motivasi belajar merupakan bekal utama dalam pencapaian tujuan pembelajaran. Motivasi dapat menggerakkan manusia untuk menampilkan suatu tingkah laku kearah pencapaian suatu tujuan. Motivasi dalam belajar sangat penting dan tidak dapat dipisahkan dari diri siswa, karena tanpa adanya motivasi belajar siswa tidak akan mendapatkan prestasi belajar yang tinggi, siswa akan malas dalam belajar dan tidak mempunyai semangat untuk berprestasi, dengan kata lain prestasi belajar akan menjadi rendah. Kabupaten Gunungkidul memiliki Angka Partisipasi Kasar (APK) pada tahun 2011 untuk tingkat SMK sebesar $70,74 \%$ yang artinya sebanyak $70,74 \%$ siswa pada umur 16-18 tahun yang sekolah pada jenjang SMK dan sebanyak 29,26 \% siswa masih belum memperoleh pendidikan pada jenjang SMK. Kesadaran warga Gunungkidul masih kurang terhadap pentingnya pendidikan sehingga dibutuhkan motivasi belajar yang tinggi bagi siswa yang telah memperoleh pendidikan di sekolah supaya tidak terpengaruh hal-hal yang negatif oleh teman-teman di sekitarnya yang tidak sekolah.

Berdasarkan uraian di atas maka penelitian ini penting untuk diteliti supaya didapatkan informasi tentang pemanfaatan internet, lingkungan, motivasi belajar dan prestasi belajar siswa mata diklat produktif teknik audio video SMK Negeri se-Kabupaten Gunungkidul.

\section{METODE}

\section{Jenis Penelitian}

Penelitian ini menggunakan pendekatan kuantitatif. Ditinjau dari wujud data dan teknik analisisnya termasuk dalam pendekatan kuantitatif karena data yang diperoleh berupa angka-angka dan diselesaikan dengan metode statistika. Penelitian ini merupakan jenis penelitian ex post facto karena pada penelitian ini peneliti tidak memberikan perlakuan, peneliti hanya mengungkap fenomena yang terjadi dan menelusuri penyebab-penyebab terjadinya variabel pada penelitian ini, serta mengumpulkan fakta-fakta berdasarkan pengukuran terhadap gejala yang telah ada atau yang terjadi secara wajar pada diri responden.

\section{Waktu dan Tempat Penelitian}

Penelitian ini dilaksanakan di SMK Negeri se-Kabupaten Gunungkidul pada siswa kelas X (sepuluh) Kompetensi Keahlian Teknik Audio Video, yaitu SMK N 3 Wonosari, SMK N Tepus, SMK N 1 Ponjong, SMK N 1 Saptosari, dan SMK N 1 Purwosari tahun pelajaran 2012/2013.

\section{Populasi dan Sampel}

Populasi dari penelitian ini adalah seluruh siswa kelas X (sepuluh) Kompetensi Keahlian Teknik Audio Video SMK Negeri se-Kabupaten Gunungkidul dengan jumlah 244 siswa. Pemilihan sampel menggunakan formula empiris yang dianjurkan oleh Isaac dan Michael dalam (Sukardi, 2005:55). Dari perhitungan dengan formula empiris didapatkan sampel sejumlah 149 siswa yang diambil menggunakan teknik proportional random sampling seperti disajikan pada Tabel 2. 
Tabel 2. Data Rekapitulasi Jumlah Populasi dan Sampel Siswa Kompetensi Keahlian Teknik Audio Video SMK Negeri se-Kabupaten Gunungkidul Tahun Pelajaran 2012/2013

\begin{tabular}{lcc}
\hline Nama Sekolah & $\begin{array}{c}\text { Jumlah } \\
\text { Sampel }\end{array}$ & $\begin{array}{c}\text { Jumlah } \\
\text { Populasi }\end{array}$ \\
\hline SMK N 3 Wonosari & 59 & 96 \\
SMK N Tepus & 17 & 28 \\
SMK N 1 Ponjong & 15 & 25 \\
SMK N 1 Saptosari & 38 & 62 \\
SMK N 1 Purwosari & 20 & 33 \\
\hline \multicolumn{1}{c}{ Jumlah } & 149 & 244 \\
\hline
\end{tabular}

\section{Teknik Pengumpulan Data}

Variabel dalam penelitian ini terdiri dari tiga variabel bebas (independent variable). Variabel tersebut yaitu Pemanfaatan Internet $\left(\mathrm{X}_{1}\right)$, Lingkungan $\left(\mathrm{X}_{2}\right)$ dan Motivasi Belajar $\left(\mathrm{X}_{3}\right)$. Variabel terikat (dependent variable) yaitu Prestasi Belajar (Y). Pengumpulan data untuk variabel $\mathrm{X} 1, \mathrm{X}_{2}$ dan $\mathrm{X}_{3}$ menggunakan kuesioner, sedangkan variabel Y menggunakan tes.

Validitas dalam penelitian ini menggunakan validitas isi dan validasi konstruk. Validasi isi dilakukan dengan meminta pertimbangan dari para ahli dalam bidang yang sedang diuji sedangkan validitas konstruk menggunakan rumus korelasi Product Moment. Reliabilitas dari penelitian ini dianalisis menggunakan Alpha Cronbach, sedangkan instrumen tes untuk variabel prestasi belajar pengujiannya menggunakan tingkat kesukaran dan daya beda.

\section{Teknik Analisis Data}

Teknik analisis data dalam penelitian ini menggunakan statistik deskriptif dan statistik inferensia. Untuk mendeskripsikan data digunakan nilai rerata sebagai norma perbandingan dengan lima kategori sebagai berikut:

1. Kategori sangat tinggi/sangat bagus: $>\mathrm{X}+1,5 \mathrm{SD}$

2. Kategori tinggi/bagus: $(\mathrm{X}+0,5 \mathrm{SD})-(\mathrm{X}+1,5 \mathrm{SD})$

3. Kategori cukup/cukup bagus : (X - 0,5 SD) - (X+0,5 SD)

4. Kategori rendah /buruk: $(\mathrm{X}-0,5 \mathrm{SD})$ - $(\mathrm{X}-1,5 \mathrm{SD})$

5. Kategori sangat rendah/sangat buruk: $<\mathrm{X}-1,5 \mathrm{SD}$

Dalam penelitian ini diuji dengan tiga asumsi, yaitu uji normalitas, uji linearitas, dan uji multikolinearitas. Pengujian hipotesis menggunakan analisis regresi sederhana dan analisis regresi ganda. Sebagai kriteria penerimaan dan penolakan digunakan tingkat signifikansi 5\%.

\section{HASIL PENELITIAN DAN PEMBAHASAN}

\section{Deskripsi Data}

Hasil perhitungan melalui statistik deskriptif pemanfaatan internet, lingkungan, motivasi belajar dan prestasi belajar siswa Kompetensi Keahlian Teknik Audio Video SMK Negeri se-Kabupaten Gunungkidul disajikan pada Tabel 3 dan Gambar 1.

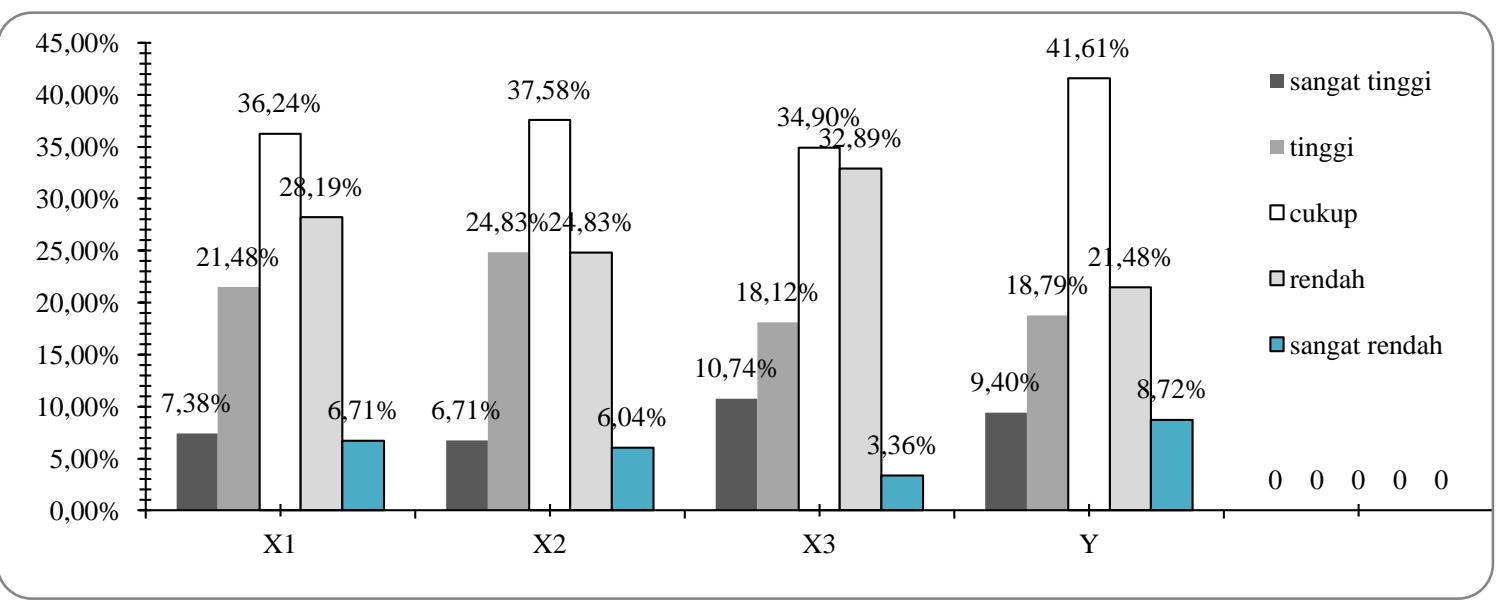

Gambar 1. Distribusi Pemanfaatan Internet $\left(\mathrm{X}_{1}\right)$, Lingkungan $\left(\mathrm{X}_{2}\right)$, Motivasi Belajar $\left(\mathrm{X}_{3}\right)$, dan Prestasi Belajar (Y) 
Tabel 3. Distribusi Pemanfaatan Internet $\left(\mathrm{X}_{1}\right)$, Lingkungan $\left(\mathrm{X}_{2}\right)$, Motivasi Belajar $\left(\mathrm{X}_{3}\right)$, dan Prestasi Belajar (Y)

\begin{tabular}{lcccccccc}
\hline \multirow{2}{*}{ Kategori } & \multicolumn{2}{c}{$\mathrm{X}_{1}$} & \multicolumn{2}{c}{$\mathrm{X}_{2}$} & \multicolumn{2}{c}{$\mathrm{X}_{3}$} & \multicolumn{2}{c}{$\mathrm{X}_{4}$} \\
& Frek & Frek (\%) & Frek & Frek (\%) & Frek & Frek (\%) & Frek & Frek (\%) \\
\hline Sangat Tinggi & 11 & 7,38 & 10 & 6,71 & 16 & 10.74 & 14 & 9,40 \\
Tinggi & 32 & 21,48 & 37 & 24,83 & 27 & 18.12 & 28 & 18,79 \\
Cukup & 54 & 36,24 & 56 & 37,58 & 52 & 34.90 & 62 & 41,61 \\
Rendah & 42 & 28,19 & 37 & 24,83 & 49 & 32.89 & 32 & 21,48 \\
Sangat Rendah & 10 & 6,71 & 9 & 6,04 & 5 & 3.36 & 13 & 8,72 \\
\hline
\end{tabular}

Pemanfaatan Internet pada siswa Kompetensi Keahlian Teknik Audio Video yang memiliki kategori sangat tinggi sebanyak 11 siswa atau $7,38 \%$, kategori tinggi sebanyak 32 siswa atau $21,48 \%$, kategori cukup sebanyak 54 siswa atau $36,24 \%$, kategori rendah sebanyak 42 siswa atau $28,19 \%$, kategori sangat rendah sebanyak 10 siswa atau $6,71 \%$. Jadi secara umum Pemanfaatan Internet siswa Kompetensi Keahlian Teknik Audio Video SMK Negeri se-Kabupaten Gunungkidul mempunyai kecenderungan dalam kategori cukup.

Lingkungan siswa Kompetensi Keahlian Teknik Audio Video yang memiliki kategori sangat bagus sebanyak 10 siswa atau $6,71 \%$, kategori bagus sebanyak 37 siswa atau $24,83 \%$, kategori cukup sebanyak 56 siswa atau $37,58 \%$, kategori buruk sebanyak 37 siswa atau $24,83 \%$, kategori sangat buruk sebanyak 9 siswa atau 6,04\%. Jadi secara umum Lingkungan pada Kompetensi Keahlian Teknik Audio Video SMK Negeri se-Kabupaten Gunungkidul mempunyai kecenderungan dalam kategori cukup.

Motivasi belajar siswa Kompetensi Keahlian Teknik Audio Video yang memiliki kategori sangat tinggi sebanyak 16 siswa atau $10,74 \%$, kategori tinggi sebanyak 27 siswa atau $18,12 \%$, kategori cukup sebanyak 52 siswa atau $34,90 \%$, kategori rendah sebanyak
49 siswa atau $32,89 \%$, kategori sangat rendah sebanyak 5 siswa atau 3,36\%. Jadi secara umum motivasi belajar pada Kompetensi Keahlian Teknik Audio Video SMK Negeri seKabupaten Gunungkidul mempunyai kecenderungan dalam kategori cukup.

Prestasi Belajar siswa Kompetensi Keahlian Teknik Audio Video yang memiliki kategori sangat tinggi sebanyak 14 siswa atau $9,40 \%$, kategori tinggi sebanyak 28 siswa atau $18,79 \%$, kategori cukup sebanyak 62 siswa atau $41,61 \%$, kategori rendah sebanyak 32 siswa atau $21,48 \%$, kategori sangat rendah sebanyak 13 siswa atau $8,72 \%$. Jadi secara umum Prestasi Belajar pada Kompetensi Keahlian Teknik Audio Video SMK Negeri seKabupaten Gunungkidul mempunyai kecenderungan dalam kategori cukup.

\section{Analisis Data}

\section{Uji Hipotesis Pertama}

Hipotesis pertama, terdapat pengaruh antara pemanfaatan internet terhadap prestasi belajar siswa. Untuk mengetahui pengaruh pemanfaatan internet terhadap prestasi belajar siswa digunakan analisis regresi linear sederhana. Berikut ini adalah tabel hasil analisis regresi linear sederhana untuk pengaruh pemanfaatan internet $\left(\mathrm{X}_{1}\right)$ terhadap prestasi belajar siswa (Y).

Tabel 4. Model Summary Pengaruh Pemanfaatan Internet terhadap Prestasi Belajar Siswa

\begin{tabular}{|c|c|c|c|c|c|c|c|c|c|}
\hline \multirow[b]{2}{*}{ Model } & \multirow[b]{2}{*}{$\mathrm{R}$} & \multirow[b]{2}{*}{ Rsquare } & \multirow[b]{2}{*}{$\begin{array}{l}\text { Adjusted } \\
\text { R Square }\end{array}$} & \multirow{2}{*}{$\begin{array}{l}\text { Std. Error } \\
\text { of the } \\
\text { Estimate }\end{array}$} & \multicolumn{5}{|c|}{ Change Statistics } \\
\hline & & & & & $\begin{array}{l}\text { R Square } \\
\text { Change }\end{array}$ & F Change & df1 & df2 & $\begin{array}{l}\text { Sig. F } \\
\text { Change }\end{array}$ \\
\hline 1 & $0,605^{\mathrm{a}}$ & 0,366 & 0,362 & 3,03260 & 0,366 & 84,850 & 1 & 147 & 0,000 \\
\hline
\end{tabular}

a.Predictors: (Constant), Internet 
Tabel 5. Koefisien Pengaruh Pemanfaatan Internet terhadap Prestasi Belajar Siswa

\begin{tabular}{|c|c|c|c|c|c|}
\hline \multirow{2}{*}{ Model } & \multicolumn{2}{|c|}{ Unstandardized Coefficients } & \multirow{2}{*}{$\begin{array}{c}\begin{array}{c}\text { Standardized } \\
\text { Coefficients }\end{array} \\
\text { Beta }\end{array}$} & \multirow[t]{2}{*}{$\mathrm{t}$} & \multirow{2}{*}{ Sig. } \\
\hline & $\mathrm{B}$ & Std. Error & & & \\
\hline (constant) & 1,696 & 1,490 & & 1,139 & 0,257 \\
\hline Internet & 0,178 & 0,019 & 0,605 & 9,211 & 0,000 \\
\hline
\end{tabular}

a. Dependent Variable: prestasi_belajar

Koefisien korelasi antara pemanfaatan internet terhadap prestasi belajar sebesar 0,605 yang artinya terdapat hubungan antara pemanfaatan internet terhadap prestasi belajar siswa. Koefisien Determinasi $(\mathrm{KD})=(0,605)^{2}$ $=0,366$ atau $36,6 \%$, yang artinya pemanfaatan internet memberikan pengaruh sebesar $36,6 \%$ terhadap prestasi belajar siswa sedangkan $63,4 \%$ dipengaruhi variabel lain yang tidak diteliti.

Untuk menguji hipotesis pertama digunakan uji t dengan menggunakan significance level 0,05 $(\alpha=5 \%)$. Dari data diatas untuk pemanfaatan internet, nilai Signifikansi sebesar $0,000<0,05$ ehingga dapat disimpulkan bahwa $\mathrm{H}_{0}$ ditolak dan Ha diterima yang berarti terdapat pengaruh antara pemanfaatan internet terhadap prestasi belajar siswa mata pelajaran dasar kompetensi kejuruan kompetensi keahlian teknik audio video SMK Negeri se-Kabupaten Gunungkidul.
Hal ini menunjukkan hipotesis yang menyatakan bahwa terdapat pengaruh antara pemanfaatan internet terhadap prestasi belajar siswa mata pelajaran dasar kompetensi kejuruan kompetensi keahlian teknik audio video SMK Negeri se-Kabupaten Gunungkidul dapat diterima dengan tingkat kepercayaan $95 \%$, dengan demikian hipotesis yang pertama pada penelitian ini dapat dibuktikan kebenarannya.

\section{Uji Hipotesis Kedua}

Hipotesis kedua, terdapat pengaruh antara lingkungan terhadap prestasi belajar siswa. Untuk mengetahui pengaruh lingkungan terhadap prestasi belajar siswa digunakan analisis regresi linear sederhana. Berikut ini adalah tabel hasil analisis regresi linear sederhana untuk pengaruh lingkungan $\left(\mathrm{X}_{2}\right)$ terhadap prestasi belajar siswa (Y).

Tabel 6. Model Summary Pengaruh Lingkungan terhadap Prestasi Belajar Siswa

\begin{tabular}{|c|c|c|c|c|c|c|c|c|c|}
\hline \multirow[b]{2}{*}{ Model } & \multirow[b]{2}{*}{$\mathrm{R}$} & \multirow[b]{2}{*}{ Rsquare } & \multirow[b]{2}{*}{$\begin{array}{l}\text { Adjusted } \\
\text { R Square }\end{array}$} & \multirow{2}{*}{$\begin{array}{l}\text { Std. Error } \\
\text { of the } \\
\text { Estimate }\end{array}$} & \multicolumn{5}{|c|}{ Change Statistics } \\
\hline & & & & & $\begin{array}{l}\text { R Square } \\
\text { Change }\end{array}$ & F Change & df1 & df2 & $\begin{array}{l}\text { Sig. F } \\
\text { Change }\end{array}$ \\
\hline 1 & $0,571^{\mathrm{a}}$ & 0,326 & 0,322 & 3,12561 & 0,326 & 71,257 & 1 & 147 & 0,000 \\
\hline
\end{tabular}

a.Predictors: (Constant), lingkungan

Tabel 7. Coefficients Pengaruh Lingkungan terhadap Prestasi Belajar Siswa

\begin{tabular}{lcccccc}
\hline \multirow{2}{*}{ Model } & \multicolumn{2}{c}{ Unstandardized Coefficients } & $\begin{array}{c}\text { Standardized } \\
\text { Coefficients }\end{array}$ & & \multirow{2}{*}{ S } \\
\cline { 2 - 4 } & $\mathrm{B}$ & Std. Error & Beta & & \\
\hline 1 & (constant) & 1,473 & 1,649 & & 0,893 & 0,373 \\
& lingkungan & 0,170 & 0,020 & 0,571 & 8,411 & 0,000 \\
\hline
\end{tabular}

a. Dependent Variable: prestasi_belajar 
Koefisien korelasi antara lingkungan terhadap prestasi belajar sebesar 0,571 yang artinya terdapat hubungan antara lingkungan terhadap prestasi belajar siswa. Koefisien Determinasi $(\mathrm{KD})=(0,571)^{2}=0,326$ atau $32,6 \%$, yang artinya lingkungan memberikan pengaruh sebesar $36,6 \%$ terhadap prestasi belajar siswa sedangkan $67,4 \%$ dipengaruhi variabel lain yang tidak diteliti.

Untuk menguji hipotesis kedua digunakan uji $\mathrm{t}$ dengan menggunakan significance level $0,05(\alpha=5 \%)$. Dari data diatas untuk lingkungan nilai Signifikansi sebesar $0,000<$ 0,05 sehingga dapat disimpulkan bahwa $\mathrm{H}_{0}$ ditolak dan Ha diterima yang berarti terdapat pengaruh antara lingkungan terhadap prestasi belajar siswa mata pelajaran dasar kompetensi kejuruan kompetensi keahlian teknik audio video SMK Negeri se-Kabupaten Gunungkidul.
Hal ini menunjukkan hipotesis yang menyatakan bahwa terdapat pengaruh antara lingkungan terhadap prestasi belajar siswa mata pelajaran dasar kompetensi kejuruan kompetensi keahlian teknik audio video SMK Negeri se-Kabupaten Gunungkidul dapat diterima dengan tingkat kepercayaan 95\%, dengan demikian hipotesis yang kedua pada penelitian ini dapat dibuktikan kebenarannya.

\section{Uji Hipotesis Ketiga}

Hipotesis ketiga, terdapat pengaruh antara motivasi belajar terhadap prestasi belajar siswa. Untuk mengetahui pengaruh motivasi belajar terhadap prestasi belajar siswa digunakan analisis regresi linear sederhana. Berikut ini adalah tabel hasil analisis regresi linear sederhana untuk pengaruh motivasi belajar $\left(\mathrm{X}_{3}\right)$ terhadap prestasi belajar siswa $(\mathrm{Y})$.

Tabel 8. Model Summary Pengaruh Motivasi Belajar terhadap Prestasi Belajar Siswa

\begin{tabular}{|c|c|c|c|c|c|c|c|c|c|}
\hline \multirow[b]{2}{*}{ Model } & \multirow[b]{2}{*}{$\mathrm{R}$} & \multirow[b]{2}{*}{ Rsquare } & \multirow[b]{2}{*}{$\begin{array}{l}\text { Adjusted } \\
\text { R Square }\end{array}$} & \multirow{2}{*}{$\begin{array}{l}\text { Std. Error } \\
\text { of the } \\
\text { Estimate }\end{array}$} & \multicolumn{5}{|c|}{ Change Statistics } \\
\hline & & & & & $\begin{array}{l}\text { R Square } \\
\text { Change }\end{array}$ & F Change & df1 & df2 & $\begin{array}{l}\text { Sig. F } \\
\text { Change }\end{array}$ \\
\hline 1 & $0,488^{\mathrm{a}}$ & 0,238 & 0,233 & 3,32392 & 0,238 & 45,990 & 1 & 147 & 0,000 \\
\hline
\end{tabular}

a.Predictors: (Constant), motivasi_belajar

Tabel 9. Coefficients Pengaruh Motivasi Belajar terhadap Prestasi Belajar Siswa

\begin{tabular}{|c|c|c|c|c|c|}
\hline \multirow[t]{2}{*}{ Model } & \multicolumn{2}{|c|}{ Unstandardized Coefficients } & \multirow{2}{*}{$\begin{array}{c}\begin{array}{c}\text { Standardized } \\
\text { Coefficients }\end{array} \\
\text { Beta }\end{array}$} & \multirow[t]{2}{*}{$\mathrm{t}$} & \multirow[t]{2}{*}{ Sig. } \\
\hline & B & Std. Error & & & \\
\hline (constant) & 0,407 & 2,202 & & 0,185 & 0,854 \\
\hline $\begin{array}{c}\text { Motivasi_ } \\
\text { belajar }\end{array}$ & 0,144 & 0,021 & 0,488 & 6,782 & 0,000 \\
\hline
\end{tabular}

a. Dependent Variable: prestasi_belajar

Koefisien korelasi antara motivasi belajar terhadap prestasi belajar sebesar 0,488 yang artinya terdapat hubungan antara motivasi belajar terhadap prestasi belajar siswa. Koefisien Determinasi $(\mathrm{KD})=(0,488)^{2}=$ 0,238 atau $23,8 \%$, yang artinya motivasi belajar memberikan pengaruh sebesar $23,8 \%$ terhadap prestasi belajar siswa sedangkan $76,2 \%$ dipengaruhi variabel lain yang tidak diteliti.

Untuk menguji hipotesis ketiga digunakan uji $\mathrm{t}$ dengan menggunakan significance level $0,05(\alpha=5 \%)$. Dari data diatas untuk motivasi belajar nilai Signifikansi sebesar $0,000<0,05$ sehingga dapat disimpulkan bahwa $\mathrm{H}_{0}$ ditolak dan $\mathrm{Ha}$ diterima yang berarti terdapat pengaruh antara motivasi belajar terhadap prestasi belajar siswa mata pelajaran dasar kompetensi kejuruan kompetensi keahlian teknik audio video SMK Negeri seKabupaten Gunungkidul.

Hal ini menunjukkan hipotesis yang menyatakan bahwa terdapat pengaruh antara motivasi belajar terhadap prestasi belajar siswa mata pelajaran dasar kompetensi ke- 
juruan kompetensi keahlian teknik audio video SMK Negeri se-Kabupaten Gunungkidul dapat diterima dengan tingkat kepercayaan $95 \%$, dengan demikian hipotesis yang ketiga pada penelitian ini dapat dibuktikan kebenarannya.

\section{Uji Hipotesis Keempat}

Hipotesis keempat, terdapat pengaruh antara pemanfaatan internet, lingkungan dan motivasi belajar terhadap prestasi belajar siswa. Untuk mengetahui pengaruh antara pemanfaatan internet, lingkungan dan motivasi belajar terhadap prestasi belajar siswa digunakan analisis regresi linear ganda. Berikut ini adalah tabel hasil analisis regresi linear ganda untuk pengaruh antara pemanfaatan internet $\left(\mathrm{X}_{1}\right)$, lingkungan $\left(\mathrm{X}_{2}\right)$ dan motivasi belajar $\left(\mathrm{X}_{3}\right)$ terhadap prestasi belajar siswa $(\mathrm{Y})$.

Tabel 10. Model Summary Pengaruh Pemanfaatan Internet, Lingkungan dan Motivasi Belajar terhadap Prestasi Belajar Siswa

\begin{tabular}{|c|c|c|c|c|c|c|c|c|c|}
\hline \multirow[b]{2}{*}{ Model } & \multirow[b]{2}{*}{$\mathrm{R}$} & \multirow[b]{2}{*}{ Rsquare } & \multirow[b]{2}{*}{$\begin{array}{l}\text { Adjusted } \\
\text { R Square }\end{array}$} & \multirow{2}{*}{$\begin{array}{l}\text { Std. Error } \\
\text { of the } \\
\text { Estimate }\end{array}$} & \multicolumn{5}{|c|}{ Change Statistics } \\
\hline & & & & & $\begin{array}{l}\text { R Square } \\
\text { Change }\end{array}$ & F Change & df1 & df2 & $\begin{array}{l}\text { Sig. F } \\
\text { Change }\end{array}$ \\
\hline 1 & $0,607^{\mathrm{a}}$ & 0,368 & 0,355 & 3,304823 & 0,368 & 28,159 & 1 & 145 & 0,000 \\
\hline
\end{tabular}

a.Predictors: (Constant), motivasi_belajar, internet, lingkungan

Tabel 11. Anova Pengaruh Pemanfaatan Internet, Lingkungan dan Motivasi Belajar terhadap Prestasi Belajar Siswa

\begin{tabular}{lccccc}
\hline \multirow{2}{*}{ Model } & & & & & \multirow{2}{*}{ Sig. } \\
\cline { 2 - 4 } & $\begin{array}{c}\text { Sum of } \\
\text { Squares }\end{array}$ & df & Mean Square & F & \\
\hline 1 Regressio & 784,940 & 3 & 261,647 & 28,159 & $0,00^{\mathrm{a}}$ \\
Residual & 1347,302 & 145 & 9,292 & & \\
Total & 2132,242 & 148 & & & \\
\hline
\end{tabular}

a.Predictors: (Constant), motivasi_belajar, internet, lingkungan

b.Dependent Variable: prestasi_belajar

Koefisien korelasi antara pemanfaatan internet, lingkungan dan motivasi belajar secara bersama-sama terhadap prestasi belajar sebesar 0,607 yang artinya terdapat hubungan antara pemanfaatan internet, lingkungan dan motivasi belajar secara bersama-sama terhadap prestasi belajar siswa. Koefisien Determinasi $(\mathrm{KD})=(0,607)^{2}=0,368$ atau $36,8 \%$, yang artinya pemanfaatan internet, lingkungan dan motivasi belajar secara bersama-sama memberikan pengaruh sebesar $36,8 \%$ terhadap prestasi belajar siswa sedangkan $63,2 \%$ dipengaruhi variabel lain yang tidak diteliti.

Untuk menguji hipotesis keempat digunakan uji $\mathrm{F}$ dengan menggunakan significance level $0,05(\alpha=5 \%)$. Dari data diatas untuk diperoleh nilai Signifikansi sebesar $0,000<0,05$ dan sehingga dapat disimpulkan bahwa $\mathrm{H}_{0}$ ditolak dan Ha diterima yang berarti terdapat pengaruh antara pemanfaatan internet, lingkungan dan motivasi belajar terhadap prestasi belajar siswa mata pelajaran dasar kompetensi kejuruan kompetensi keahlian teknik audio video SMK Negeri se-Kabupaten Gunungkidul.

Hal ini menunjukkan hipotesis yang menyatakan bahwa terdapat pengaruh antara pemanfaatan internet, lingkungan dan motivasi belajar terhadap prestasi belajar siswa mata pelajaran dasar kompetensi kejuruan kompetensi keahlian teknik audio video SMK Negeri se-Kabupaten Gunungkidul dapat diterima dengan tingkat kepercayaan 95\%, dengan demikian hipotesis yang keempat pada penelitian ini dapat dibuktikan kebenarannya. 


\section{Pemanfaatan internet siswa kompetensi keahlian teknik audio video SMK Negeri se-Kabupaten Gunungkidul}

Pemanfaatan internet siswa kompetensi keahlian teknik audio video yang memiliki kecenderungan pada kategori sangat tinggi sebesar 7,38\%, yang memiliki kecenderungan pada kategori tinggi sebesar $21,48 \%$, yang memiliki kecenderungan pada kategori cukup sebesar $36,24 \%$, yang memiliki kecenderungan pada kategori rendah sebesar $28,19 \%$, dan yang memiliki kecenderungan pada kategori sangat rendah sebesar $6,71 \%$. Hal ini menunjukkan bahwa pemanfaatan internet siswa kompetensi keahlian teknik audio video SMK Negeri se-Kabupaten Gunungkidul termasuk dalam kategori cukup.

Pemanfaatan internet siswa kompetensi keahlian teknik audio video SMK Negeri seKabupaten Gunungkidul dapat ditingkatkan apabila siswa memiliki pengetahuan tentang komputer dan internet, mampu menggunakan internet misalnya mampu menggunakan email, chatting, browsing, search engine, download, serta siswa harus meningkatkan intensitas dalam menggunakan internet supaya terbiasa dengan internet, dalam proses belajar mengajar siswa harus aktif menggunakan internet untuk mencari referensi atau sumber belajar yang tak terbatas di internet yang berkaitan dengan materi pelajaran yang sedang diajarkan oleh guru untuk belajar, sarana dan prasarana yaitu perbaikan sarana dan prasarana pendukung untuk mengakses internet pada saat di lingkungan sekolah dan diluar lingkungan sekolah sehingga siswa dapat memanfaatkan internet sebagai sarana sumber belajar yang tak terbatas.

Hal ini relevan dengan hasil penelitian yang dilakukan oleh Sahin, Balta, dan Ercan (2010) yang menunjukkan hasil bahwa penggunaan internet merupakan hal yang sangat penting untuk kegitan belajar mengajar, khususnya dikelas yang lebih tinggi karena lebih membutuhkan kajian literatur. Internet bagi siswa dimanfaatkan sebagai sarana pencarian informasi/data, selain itu internet dapat dimanfaatkan sebagai sarana komunikasi karena teknologi internet ini menunjang para siswa yang mengalami keterbatasan ruang dan waktu untuk tetap dapat menikmati pendidikan mereka. Komunikasi yang digunakan adalah melalui e-mail, mailing list dan chatting yang dapat dimanfaatkan sebagai media diskusi.

Hal ini senada dengan hasil penelitian yang dilakukan oleh Pei Wen Liao \& Jun Yi Hsieh (2011) yang menunjukkan bahwa pembelajaran berbasis inernet dapat meningkatkan kepuasan belajar siswa dan kepuasan belajar siswa mempunyai peran yang sangat penting untuk meningkatkan kinerja siswa.

\section{Lingkungan Siswa Kompetensi Keahlian Teknik Audio Video SMK Negeri se- Kabupaten Gunungkidul}

Lingkungan siswa kompetensi keahlian teknik audio video yang memiliki kecenderungan pada kategori sangat baik sebesar $6,71 \%$, yang memiliki kecenderungan pada kategori baik sebesar $24,83 \%$, yang memiliki kecenderungan pada kategori cukup sebesar $37,58 \%$, yang memiliki kecenderungan pada kategori buruk sebesar $24,83 \%$, dan yang memiliki kecenderungan pada kategori sangat buruk sebesar $6,04 \%$. Hal ini menunjukkan bahwa lingkungan siswa kompetensi keahlian teknik audio video SMK Negeri se-Kabupaten Gunungkidul termasuk dalam kategori cukup.

Lingkungan siswa kompetensi keahlian teknik audio video SMK Negeri se-Kabupaten Gunungkidul akan menjadi baik apabila dalam lingkungan keluarga orang tua mendidik siswa dengan memberikan perhatiannya untuk kemajuan belajar siswa, relasi antar anggota keluarga baik misalnya komunikasi dan hubungan antar anggota keluarga harmonis, suasana rumah nyaman dan tenang jauh dari kebisingan supaya siswa dapat berkonsentrasi dalam belajar, keadaan ekonomi keluarga yang baik untuk memenuhi fasilitas belajar siswa. Dalam lingkungan sekolah relasi antara siswa, karyawan dan guru berjalan dengan baik, siswa harus mematuh tata tertib yang ada di sekolah misalnya tidak boleh terlambat memasuki kelas, siswa menggunakan alat-alat praktek sesuai dengan prosedurnya sehingga alat praktek menjadi awet dan keadaannya selalu bagus apabila akan digunakan untuk praktek, siswa mengerjakan tugas yang diberikan oleh guru secara sungguh-sungguh dan dikerjakan secara mandiri supaya dapat diketahui sejauhmana kemampuan siswa dalam memahami materi pelajaran. Dalam lingkungan masyarakat siswa sebaiknya mengikuti kegiatan karang taruna yang ada di dalam masyarakat serta melibatkan diri dalam 
kegiatan sosial, siswa harus berani menolak jika diajak oleh teman di dalam masyarakat apabila diajak untuk tidak belajar dan melakukan kegiatan yang negatif misalnya nongkrong dan begadang pada waktu malam hari yang tidak ada gunanya.

Hal ini relevan dengan penelitian yang dilakukan oleh Hara dan Burke (1998) yang menunjukkan hasil bahwa dukungan orang tua yang baik bagi siswa akan dapat meningkatkan prestasi belajar siswa dan sikap siswa terhadap pembelajaran. Selain itu Higgins, Hall, Wall, Woolner, dan McCaughey (2005) menjelaskan bahwa elemen fisik di lingkungan sekolah dapat terbukti memiliki efek yang jelas terhadap guru dan peserta didik. Secara khusus, kontrol suhu yang tidak memadai, pencahayaan, kualitas udara dan akustik memiliki efek merugikan pada konsentrasi, semangat, kesejahteraan, kehadiran dan, pada akhirnya akan berdampak pada pencapaian prestasi belajar siswa.

\section{Motivasi Belajar Siswa Kompetensi Kejuruan Kompetensi Keahlian Teknik Audio Video SMK Negeri se-Kabupaten Gunungkidul}

Motivasi belajar siswa kompetensi keahlian teknik audio video yang memiliki kecenderungan pada kategori sangat tinggi sebesar $10,74 \%$, yang memiliki kecenderungan pada kategori tinggi sebesar $18,12 \%$, yang memiliki kecenderungan pada kategori cukup sebesar 34,90\%, yang memiliki kecenderungan pada kategori rendah sebesar $32,89 \%$, dan yang memiliki kecenderungan pada kategori sangat rendah sebesar 3,36\%. Hal ini menunjukkan bahwa lingkungan siswa kompetensi keahlian teknik audio video SMK Negeri seKabupaten Gunungkidul termasuk dalam kategori cukup.

Motivasi belajar siswa kompetensi keahlian teknik audio video SMK Negeri seKabupaten Gunungkidul dapat ditingkatkan apabila siswa tekun dalam melakukan pembelajaran di sekolah misalnya selalu datang ke sekolah sebelum bel masuk berbunyi, siswa aktif dalam mengikuti pembelajaran pada saat di kelas, siswa mempunyai jam belajar yang teratur pada saat berada di rumah, keuletan dalam menghadapi kesulitan belajar misalnya siswa tidak cepat putus asa ketika mengalami kesulitan dalam pembelajaran, siswa harus berusaha secara terus menerus dalam me- ngerjakan tugas dari guru sebelum tugas itu selesai, perhatian dalam melakukan pembelajaran misalnya siswa harus berkonsentrasi untuk memperhatikan materi yang diajarkan oleh guru pada saat pembelajaran, sebaiknya siswa belajar terlebih dahulu di rumah supaya siap menerima pelajaran pada waktu di sekolah, berprestasi dalam melakukan pembelajaran misalnya siswa sebaiknya berusaha memperoleh nilai yang tinggi dalam menempuh tes, mandiri dalam melakukan pembelajaran misalnya tugas-tugas dikerjakan dengan usaha sendiri, menggunakan waktu luang untuk diskusi tentang mata pelajaran yang dianggap sukar dengan teman.

Hal ini relevan dengan penelitian yang dilakukan oleh Noordin Yahaya, Azizi Yahaya, Jamaludin Ramli, Shahrin Hashim, dan Zurihanmi Zakariya (2010) yang menunjukkan hasil bahwa faktor motivasi ekstrinsik dalam belajar matematika antara siswa di sekolah menengah seperti fasilitas, asosiasi orang tua dengan guru, guru, keluarga, teman sebaya, lingkungan, dan bahasa mempunyai pengaruh secara signifikan terhadap prestasi belajar siswa. Hal ini sejalan dengan hasil penelitian yang dilakukan oleh Ames dan Archer (1998) yang menunjukkan hasil bahwa semua siswa telah mendapatkan nilai di atas kriteria ketuntasan minimal pada standar prestasi belajar siswa. Pola motivasi belajar siswa yang memiliki prestasi belajar yang baik akan memiliki tujuan dan orientasi dalam diri siswa itu sendiri.

\section{Prestasi Belajar Siswa Mata Pelajaran Dasar Kompetensi Kejuruan Kompetensi Keahlian Teknik Audio Video SMK Negeri se-Kabupaten Gunungkidul}

Prestasi belajar siswa kompetensi keahlian teknik audio video yang memiliki kecenderungan pada kategori sangat tinggi sebesar $9,40 \%$, yang memiliki kecenderungan pada kategori tinggi sebesar $18,79 \%$, yang memiliki kecenderungan pada kategori cukup sebesar $41,61 \%$, yang memiliki kecenderungan pada kategori rendah sebesar $21,48 \%$, dan yang memiliki kecenderungan pada kategori sangat rendah sebesar $8,72 \%$. Hal ini menunjukkan bahwa prestasi belajar siswa kompetensi keahlian teknik audio video SMK Negeri se-Kabupaten Gunungkidul termasuk dalam kategori cukup. 
Siswa dikatakan memenuhi kriteria ketuntasan minimal (KKM) dalam belajar untuk mata diklat pelajaran produktif mengacu kepada standar minimal penguasaan kompetensi yang berlaku di dunia kerja yang bersangkutan. Kriteria ideal ketuntasan untuk masing-masing indikator pada kompetensi dasar program produktif pada dasarnya adalah kompeten/tidak kompeten. Apabila nilai siswa tidak kompeten maka siswa tersebut belum memenuhi syarat untuk mengikuti mata pelajaran standar kompetensi selanjutnya dan siswa tersebut harus melakukan proses perbaikan nilai sampai siswa tersebut memperoleh nilai kriteria ketuntasan minimal yang ditetapkan oleh sekolah, tetapi jika nilai siswa sudah kompeten maka siswa tersebut sudah memenuhi syarat untuk mengikuti mata pelajaran standar kompetensi selanjutnya.

Hal ini relevan dengan penelitian yang dilakukan oleh Martens dan Flowers (2003) yang menunjukkan hasil bahwa tingkat pendapatan keluarga siswa memiliki pengaruh terhadap prestasi belajar siswa. Sebagian besar sekolah yang memiliki banyak jumlah siswa yang berpenghasilan rendah dapat mempengaruhi nilai prestasi belajar siswa.

\section{Pengaruh Pemanfaatan Internet terhadap Prestasi Belajar Siswa Mata Pelajaran Dasar Kompetensi Kejuruan Kompetensi Keahlian Teknik Audio Video SMK Negeri se-Kabupaten Gunungkidul}

Berdasarkan penelitian yang dilakukan pada siswa kompetensi keahlian teknik audio video SMK Negeri se-Kabupaten Gunungkidul didapatkan hasil bahwa terdapat pengaruh pemanfaatan internet $\left(\mathrm{X}_{1}\right)$ terhadap prestasi belajar siswa (Y) mata pelajaran dasar kompetensi kejuruan kompetensi keahlian teknik audio video SMK Negeri se-Kabupaten Gunungkidul.

Hal tersebut relevan dengan hasil penelitian yang dilakukan oleh Goyal, Purohit, dan Bhaga (2011) yang menunjukkan hasil bahwa kinerja siswa dipengaruhi oleh penggunaan internet, sebagian besar siswa merasa puas dengan informasi yang mereka temukan di internet dan penggunaan internet dapat bermanfaat untuk meningkatkan kinerja siswa. Hal ini sejalan dengan hasil penelitian yang dilakukan oleh Su Yen Chen dan Yang Chih Fu (2009) yang menunjukkan hasil bahwa penggunaan internet berpengaruh terhadap prestasi belajar siswa pada Sekolah Menengah, apabila internet digunakan untuk mencari informasi yang positif maka akan meningkatkan prestasi belajar siswa.

Koefisien Determinasi sebesar 0,366 atau $36,6 \%$ menunjukkan bahwa pemanfaatan internet memberikan pengaruh sebesar $36,6 \%$ terhadap prestasi belajar siswa sedangkan $63,4 \%$ dipengaruhi oleh variabel lain yang tidak diteliti, artiya variabel pemanfaatan internet dapat dijadikan indikator keberhasilan untuk meningkatkan prestasi belajar siswa mata pelajaran dasar kompetensi kejuruan kompetensi keahlian teknik audio video SMK Negeri se-Kabupaten Gunungkidul disamping variabel-variabel lainnya yang juga berpengaruh besar terhadap peningkatan prestasi belajar siswa.

\section{Pengaruh Lingkungan terhadap Prestasi Belajar Siswa Mata Pelajaran Dasar Kom- petensi Kejuruan Kompetensi Keahlian Teknik Audio Video SMK Negeri se- Kabupaten Gunungkidul}

Berdasarkan penelitian yang dilakukan pada siswa kompetensi keahlian teknik audio video SMK Negeri se-Kabupaten Gunungkidul didapatkan hasil bahwa terdapat pengaruh lingkungan $\left(\mathrm{X}_{2}\right)$ terhadap prestasi belajar siswa (Y) mata pelajaran dasar kompetensi kejuruan kompetensi keahlian teknik audio video SMK Negeri se-Kabupaten Gunungkidul.

Hal tersebut relevan dengan penelitian yang dilakukan oleh Bagus Indrawan (2012) yang menunjukkan hasil bahwa terdapat pengaruh positif dan signifikan lingkungan belajar siswa dengan prestasi belajar akuntansi pada siswa kelas XI IPS SMA Negeri 1 Pakem tahun ajaran 2011/2012. Hal ini sejalan dengan $\mathrm{Hal}$ ini relevan dengan penelitian yang dilakukan oleh Houtenville dan Conway (2008) yang menunjukkan hasil bahwa peranan orang tua dalam lingkungan keluarga mempunyai pengaruh yang kuat terhadap prestasi belajar siswa.

Koefisien Determinasi sebesar 0,326 atau 32,6\% menunjukkan bahwa lingkungan memberikan pengaruh sebesar $32,6 \%$ terhadap prestasi belajar siswa sedangkan $67,4 \%$ dipengaruhi oleh variabel lain yang tidak diteliti, artiya variabel lingkungan dapat dijadikan indikator keberhasilan untuk meningkatkan prestasi belajar siswa mata pelajaran 
dasar kompetensi kejuruan kompetensi keahlian teknik audio video SMK Negeri seKabupaten Gunungkidul disamping variabelvariabel lainnya yang juga berpengaruh besar terhadap peningkatan prestasi belajar siswa.

\section{Pengaruh Motivasi Belajar terhadap Pres- tasi Belajar Siswa Mata Pelajaran Dasar Kompetensi Kejuruan Kompetensi Keahlian Teknik Audio Video SMK Negeri se-Kabupaten Gunungkidul}

Berdasarkan penelitian yang dilakukan pada siswa kompetensi keahlian teknik audio video SMK Negeri se-Kabupaten Gunungkidul didapatkan hasil bahwa terdapat pengaruh motivasi belajar $\left(\mathrm{X}_{3}\right)$ terhadap prestasi belajar siswa (Y) mata pelajaran dasar kompetensi kejuruan kompetensi keahlian teknik audio video SMK Negeri se-Kabupaten Gunungkidul.

Hal tersebut relevan dengan penelitian yang dilakukan oleh Lee, I. (2010) yang menunjuukan hasil bahwa motivasi belajar siswa berpengaruh positif terhadap prestasi belajar. Hal ini senada dengan Adedeji Tella (2007) yang menunjukkan hasil bahwa motivasi belajar mempunyai pengaruh terhadap prestasi belajar siswa dan siswa yang mempunyai motivasi tinggi akan tampil lebih baik secara akademis daripada siswa yang memiliki motivasi rendah.

Koefisien Determinasi sebesar 0,238 atau $23,8 \%$ menunjukkan bahwa motivasi belajar memberikan pengaruh sebesar 23,8\% terhadap prestasi belajar siswa sedangkan $76,2 \%$ dipengaruhi oleh variabel lain yang tidak diteliti, artiya variabel motivasi belajar dapat dijadikan indikator keberhasilan untuk meningkatkan prestasi belajar siswa mata pelajaran dasar kompetensi kejuruan kompetensi keahlian teknik audio video SMK Negeri se-Kabupaten Gunungkidul disamping variabel-variabel lainnya yang juga berpengaruh besar terhadap peningkatan prestasi belajar siswa.

\section{Pengaruh Pemanfaatan Internet, Lingkungan dan Motivasi Belajar terhadap Prestasi Belajar Siswa Mata Pelajaran Dasar Kompetensi Kejuruan Kompetensi Keahlian Teknik Audio Video SMK Negeri se-Kabupaten Gunungkidul}

Berdasarkan penelitian yang dilakukan pada siswa kompetensi keahlian teknik audio video SMK Negeri se-Kabupaten Gunungkidul didapatkan hasil bahwa terdapat pengaruh pemanfaatan internet $\left(\mathrm{X}_{1}\right)$, lingkungan $\left(X_{2}\right)$ dan motivasi belajar $\left(X_{3}\right)$ terhadap prestasi belajar siswa (Y) mata pelajaran dasar kompetensi kejuruan kompetensi keahlian teknik audio video SMK Negeri se-Kabupaten Gunungkidul.

Hal ini relevan dengan hasil penelitian yang dilakukan oleh Young (2006) yang menunjukkan bahwa penggunaan internet dan modal sosial remaja secara signifikan berpengaruh dengan prestasi belajar. Para remaja menggunakan internet secara ekstensif untuk kegiatan belajar karena internet merupakan saah satu sumber informasi untuk mencari pengetahuan umum untuk menambah wawasan belajar. Selain itu hasil penelitian yang dilakukan oleh Sunitha (2005) yang menunjukkan hasil bahwa a) lingkungan belajar di rumah memiliki pengaruh positif dan signifikan terhadap lingkungan belajar di sekolah; 2) status sosial ekonomi memiliki pengaruh positif dan signifikan terhadap lingkungan belajar di rumah, lingkungan belajar sekolah dan prestasi belajar siswa. Lingkungan belajar di sekolah dan lingkungan belajar di rumah merupakan hal yang sangat penting untuk peningkatan prestasi belajar siswa sehingga orang tua perlu menciptakan lingkungan yang menyenangkan pada saat di rumah, memberikan dorongan, stimulasi dan mengembangkan strategi yang baik dalam mendidik siswa sehingga akan meningkatkan prestasi belajar siswa.

Lebih lanjut Hasil penelitian Atta dan Jamil (2012) yang menunjukkan hasil bahwa terdapat pengaruh yang signifikan dan positif antara motivasi belajar dan pengaruh orang tua terhadap prestasi belajar siswa. Dukungan orang tua akan memberikan dampak pada siswa karena siswa yang di dukung oleh orang tua akan memiliki motivasi yang lebih baik.

Koefisien Determinasi sebesar 0,368 atau 36,8\% menunjukkan bahwa pemanfaatan internet, lingkungan dan motivasi belajar memberikan pengaruh sebesar $36,8 \%$ terhadap prestasi belajar siswa sedangkan $63,2 \%$ dipengaruhi oleh variabel lain yang tidak diteliti, artiya variabel pemanfaatan internet, lingkungan dan motivasi belajar dapat dijadikan indikator keberhasilan untuk meningkatkan prestasi belajar siswa mata pelajaran dasar kompetensi kejuruan kompetensi keahlian 
teknik audio video SMK Negeri se-Kabupaten Gunungkidul disamping variabel-variabel lainnya yang juga berpengaruh besar terhadap peningkatan prestasi belajar siswa.

\section{SIMPULAN DAN SARAN}

\section{Simpulan}

Dari hasil penelitian yang telah dilakukan maka dapat ditarik kesimpulan sebagai berikut:

1. Gambaran umum tentang pemanfaatan internet siswa kompetensi keahlian teknik audio video SMK Negeri se-Kabupaten Gunungkidul mempunyai kecenderungan dalam kategori cukup dengan rata-rata skor sebesar 75,87; lingkungan siswa kompetensi keahlian teknik audio video SMK Negeri se-Kabupaten Gunungkidul mempunyai kecenderungan dalam kategori cukup dengan rata-rata skor sebesar 81,10; motivasi belajar siswa kompetensi keahlian teknik audio video SMK Negeri seKabupaten Gunungkidul mempunyai kecenderungan dalam kategori cukup dengan rata-rata skor sebesar 102,62 dan prestasi belajar siswa kompetensi keahlian teknik audio video SMK Negeri se-Kabupaten Gunungkidul mempunyai kecenderungan dalam kategori cukup dengan rata-rata skor sebesar 15,23.

2. Pemanfaatan internet mempunyai pengaruh terhadap prestasi belajar siswa mata pelajaran dasar kompetensi kejuruan kompetensi keahlian teknik audio video SMK Negeri se-Kabupaten Gunungkidul, lingkungan mempunyai pengaruh terhadap prestasi belajar siswa mata pelajaran dasar kompetensi kejuruan kompetensi keahlian teknik audio video SMK Negeri seKabupaten Gunungkidul, motivasi belajar mempunyai pengaruh terhadap prestasi belajar siswa mata pelajaran dasar kompetensi kejuruan kompetensi keahlian teknik audio video SMK Negeri se-Kabupaten Gunungkidul, pemanfaatan internet, lingkungan dan motivasi belajar secara bersama-sama mempunyai pengaruh terhadap prestasi belajar siswa mata pelajaran dasar kompetensi kejuruan kompetensi keahlian teknik audio video SMK Negeri se-Kabupaten Gunungkidul.

\section{Saran}

Berdasarkan hasil penelitian maka terdapat beberapa saran yang dapat dilakukan untuk meningkatkan prestasi belajar siswa pada mata pelajaran dasar kompetensi kejuruan kompetensi keahlian teknik audio video SMK Negeri se-Kabupaten Gunungkidul, yaitu:

1. Sarana dan prasarana untuk mengakses internet khususnya di sekolah agar diperbaiki supaya siswa dan guru dapat memanfaatkan internet untuk kegiatan pembelajaran dengan optimal. Guru mata pelajaran dasar kompetensi kejuruan kompetensi keahlian teknik audio video lebih dapat mengoptimalkan dalam memanfaatkan internet untuk pembelajaran misalnya untuk mencari materi pelajaran melalui search engine, memberikan tugas pada siswa di internet, download software tentang teknik audio video sehingga internet dapat dijadikan sebagai salah satu sumber belajar yang tak terbatas.

2. Orang tua harus mendukung dan mendorong anak-anaknya untuk lebih giat lagi belajar pada saat siswa berada di rumah. Selain itu orang tua juga harus mengetahui dan selalu mengawasi teman sepergaulannya supaya siswa terhindar dengan pergaulan yang salah di masyarakat serta adanya kerjasama dari semua pihak untuk meningkatkan prestasi belajar siswa, khususnya orang tua dengan guru, misalnya orang tua selalu berkonsultasi dengan pihak sekolah tentang perkembangan maupun prestasi belajar anak-anaknya.

3. Guru pada mata pelajaran dasar kompetensi kejuruan kompetensi keahlian teknik audio video agar lebih kreatif dan inovatif dalam memberikan materi pelajaran agar siswa lebih aktif dan antusias dalam mengikuti dan mempelajari tentang teknik audio video.

\section{DAFTAR PUSTAKA}

Ames, C., \& Archer, J. (1988). Achievement goals in the classroom: students' learning strategies and motivation processes. Journal of educational psychology, 80, 260-267.

Angka Partisipasi Kasar (APK) Kabupaten Gunungkidul. Diakses tanggal 17 
Oktober 2012, dari http://www.gunung kidulkab.go.id/pustaka/RKPD\%20 Kab.\%20Gunungkidul\%202013.pdf

Atta, M. A., \& Jamil, A. (2012). Effects of motivation and parental influence on the educational attainments of students at secondary level. Academic Research International, 2, 427-431.

Chen, S. Y., \& Fu, Y. C. (2009). Internet use and academic achievement: gender differences in early adolescence. Diakses tanggal 2 Juli 2013, dari http:// www.search.proquest.com/docview/195 938430/fulltextPDF/13F8369D5D36D B5E123/1 ?accountid $=38628$

Goyal, E., Purohit, S., Bhaga, M. (2011). Study of satisfaction and usability of the internet on student's performance. International Journal of Education and Development using Information and Communication Technology(IJEDICT), 7, 110-119.

Hamalik, O. (2003). Proses belajar mengajar. Jakarta: Bumi Aksara.

Hara, S. R., \& Burke, D. J. (1998). Parent Involvement: The Key To Improved Student Achievement. School Community Journal, 8, 219-228.

Higgins, S., Hall, E., Wall, K., et al. (Februari 2005). The impact of school environments: a literature review. Diambil pada tanggal 4 Juli 2013, dari http://www. ncl.ac.uk/cflat/news/DCReport.pdf

Houtenville , A. J., \& Conway, K. S. (2007). Parental effort, school resources, and student achievement. The Journal of Human Resources, XLIII, 437-453.

Indrawan, B. (2012). Pengaruh kemandirian belajar dan lingkungan belajar terhadap prestasi belajar akuntansi siswa kelas XI IPS SMA N 1 Pakem tahun ajaran 2011/2012. Jurnal Kajian Pendidikan \& Akuntansi Indonesia, 1, 1-22.

Lee, I.C. (2010). The effect of learning motivation, total quality teaching and peer-assisted learning on study achievement: empirical analysis from vocational universities or colleges' students in Taiwan. The Journal of Human Resource and Adult Learning, 1, 56-73.
Pei Wen Liao \& Jun Yi Hsieh. (2011). What influences internet based learning? Social Behavior and Personality ProQuest Sociology, 39, 887-896. Dari http://search.proquest.com/docview/893 092831/fulltextPDF/13F5B37116C574 966A9/1 ?accountid=31324 pada 4 Juli 2013.

Rata-rata nilai Ujian Nasional (UN) Tahun 2012 Provinsi DIY. Diakses tanggal 15 Oktober 2012, dari http://www.pen didikan-diy.go.id/?view=v_ berita\&id_ $\underline{\text { sub }=2692}$

Sahin, Y. G., Balta, S., \& Ercan, T. (2010). The use of internet resources by university students during their course projects elicitation: a case study. The Turkish Online Journal of Educational Technology, 9, 234-244.

Sardiman, A.M. (2005). Interaksi dan motivasi belajar mengajar. Jakarta: Raja Grafindo Persada.

Sukmadinata, N.S. (2003). Landasan psikologi proses pendidikan. Bandung: Remaja Rosdakarya.

Sunitha, N.H. (2005). Academic learning environment of students from aided and unaided co-educational high schools. Tesis master, tidak diterbitkan, University of Agricultural Sciences Dharwad.

Tella, A. (2007). The impact of motivation on student's academic achievement and learning outcomes in mathematics among Secondary School Students in Nigeria. Eurasia Journal of Mathematics, Science \& Technology Education, 3, 149-156.

Yahaya, N., Yahaya, A., Ramli, J., et al. (2010). The effects of extrinsic motivational factors in learning among students in secondary school in negeri sembilan. International Journal of Psychological Studies, 2, 128-136.

Young, B. (2006). A study on the effect of internet use and social capital on the academic performance. Development and Society, 35, 107-123. 